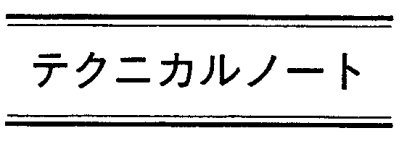

\author{
パソコンによるIr-192 の線量計算 \\ 高 橋 賢 一・石 垣 秀 世・宇田川 王 男 \\ 斉藤 正美・山口京子 \\ 千葉県がんセンター放射線治療部 \\ （論文受理１987年 5 月18日） \\ （最終論文受理１988年 2月26日） \\ (Code No. 713, 748)
}
Key words: Iridium-192, Interstitial radiotherapy, Personal computer, Three-dimensional reconstruction, Treatment planning

\title{
DOSE CALCULATION FOR IRIDIUM-192 \\ SOURCES BY A PERSONAL COMPUTER
}

\author{
Kenichi Takahashi, Hideyo Ishigaki, Kimio Udagawa \\ Masami Saito, Kyoko Yamaguchi \\ Department of radiation therapy Chiba Cancer Center
}

(Article received; May, 18, 1987)

\section{Summary}

Recently Ir-192 sources have been used for interstitial radiotherapy instead of Ra-226 needles. One end of Ir-192 (single-pin) is formed with circlet and implanted Ir-192 sources are not always straight line. So the authors have developed a new dose calculation system, in which the authers employed conventional method considering oblique filteration for linear source and multi-point source method for curved source.

Conventionally the positions of sources in three dimensions are determined from projections of the implanted sources on orthogonal or stereo radiographs. But it is frequentry impossible to define the end of sources on account of overlap. Then the authers have devised a method to determine the positions of sources from two radiographs which were taken with arbitrary direcions.

For tongue cancer injuries of mandibula so frequently occur after interstitial radiotherapy that the calculation of gingival dose is necessary. The positions of the gingival line are determind from two directinal radiographs too.

Further the three dimensional dose distributions can be displayed on the cathod ray tube.

These calculations are performed by using a personal computer because of its distinctive features such as 
superiority in cost performance and flexibility for development and modification of programs.

\section{1. 緒言}

最近舌癌等の組織内治療に Ra 針に代わって Ir-192 が使用されるようになってきた。 Ir-192 は Single-pinの ように一端が円状になっていたり，Pinの柔軟性から刺 入時に屈曲したりするので，直線状線源として取り扱え ない場合がある。また現在販売されている高価なミニコ ンを使った Ir-192 線量計算用ソフトは，曲がった線源の 線量計算は実行できないのが実情である。そこでわれわ れは安価になったパソコンを利用して Ir-192の線量計 算を行うプログラムを開発した。パソコンを使う利点は ソフトの開発，変更が容易であり，コストパフォーマン スがすぐれていることである。線量計算の方法として直 線状の線源については通常使われている方法を用い, 曲 がつた線源については最も単純な線線源を点線源に置換 することにした，この場合置換の点数についても検討し た。

線源位置の 3 次元再構成法は通常直角 2 方向撮影法が 使われるが，線源同士あるいは治療歯の重なり等のため に同定が困難な場合があるそこで線源が良く見える任 意 2 方向よりX線撮影を行い位㯰を求めるようにした。

また舌癌の組織内治療の場合, 下䫟骨上縁の障害がし ばしばみられる1つ4)。この線量を評価するためには下顎 骨上縁に沿った位置を求める必要がある。この方法とし て頭側，足側よりX線を入射して同一拡大率にて任意 2 方向の撮影を行い, digitizerにて下顎をトレースして求 めるようにした。

更に 3 次元的線量分布の表示，等線量曲面で囲まれた 体積の計算等が可能になった。

\section{2. 使用装置}

personal computer: NEC PC98XA model 2

digitizer : グラフテック KD4030A

simulator：東芝 LX-30A

\section{3. 方法}

\section{1 線量計算法}

Ir-192 の半減期は74.2日である. Ir-192を 1 週間刺入 した時，減衰がないものとして計算すると総線量で $4 \%$ の不足となるので，減衰の補正は必要である．Fig. 1 に Ir-192 single-pin および hairpin の形状を示す5).

\section{1 .1 線線源の線量計算}

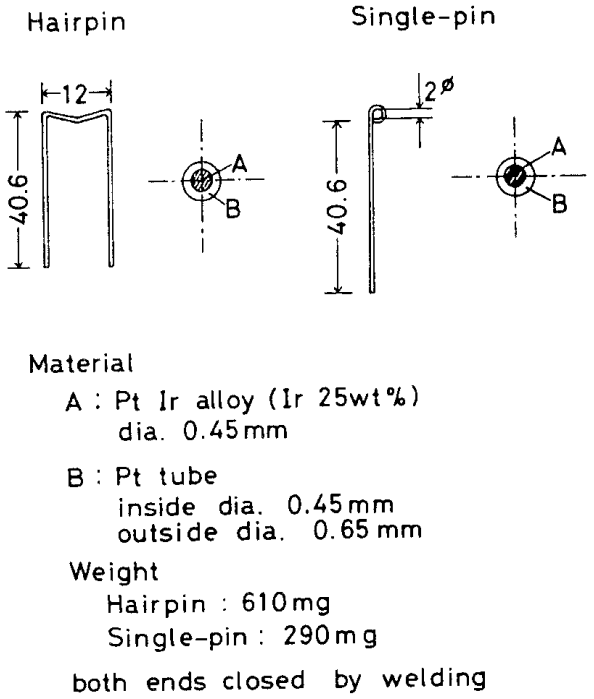

Fig. 1 Structure of $\mathrm{Ir}-192$ sources. Reprint from reference 5 .

直線状線源の場合，線量計算の方法は数多く報告され ている ${ }^{6) 10}$.われわれは文献 9,100 方法を用いてこの計 算をしている、ただし容器，自己吸収による影響を考慮 しているのでその分，放射能を増加させる必要がある. またエネルギー吸収係数については文献11の值を使って いる。微小線源 $d x$ からの吸収線量率 $d I$ は

$d I=\Gamma \cdot \frac{M}{A L} \cdot C_{\lambda} \cdot \frac{1}{r^{2}} \cdot \exp \left(-\mu_{e n} \cdot l(\theta)\right) \cdot W A R(r) \cdot d x$

したがって全線量率 $D_{L}$ は

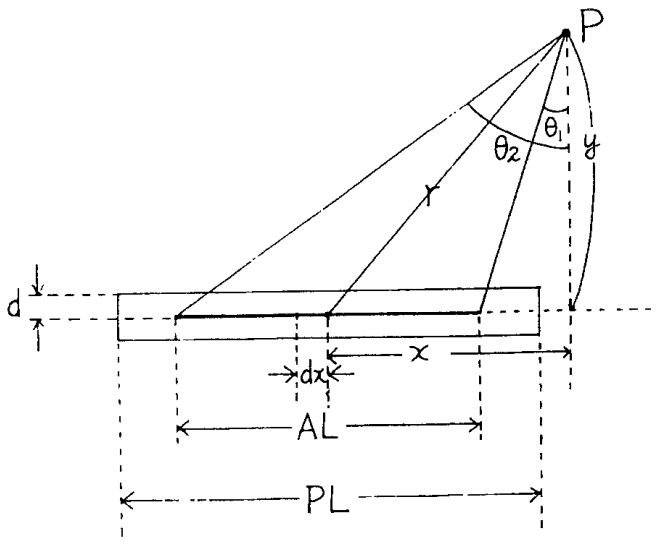

Fig. 2 Diagram illustrating the geometry and symbols usedin calculation of absorbed dose at the points near a linear source. 


$$
\begin{aligned}
D_{L}= & \Gamma \cdot \frac{M}{A L} \cdot C_{\lambda} \cdot \frac{1}{y} \cdot \int_{\theta_{1}}^{\theta_{2}} \exp \left(-\mu_{e n} \cdot l(\theta)\right) \cdot W A R(y / \\
& \cos \theta) \cdot d \theta-(2)
\end{aligned}
$$

ここで

$A L$ : active length $\quad P L:$ physical length

$d:$ 容器厚

$M:$ 放射能

$\Gamma:$ ガンマ線放射定数

$C_{\lambda}:$ 吸収線量変換係数

$l(\theta):$ 容器の $\theta$ 方向の厚さ

$$
l(\theta)=d / \cos \theta \text { or } \frac{P L}{2}+\left(y \cdot \tan \theta-x_{0}\right)
$$

$x_{0}$ は線源中心での $x$ である。

WAR: Water Air Ratio ${ }^{12}$

$$
\begin{aligned}
=1.0128 & +0.005019 \mathrm{r}-0.001178 \mathrm{r}^{2}-0.00002008 \mathrm{r}^{3} \\
1 & \leqq \mathrm{r} \leqq 10[\mathrm{~cm}]
\end{aligned}
$$

実際の線量計算は(2)式について数值積分を行い

Table 化している.

\subsection{2 曲がった線源の線量計算}

曲がつた線源および single-pin の円状になった部分は 点線源に置換する．点線源からの線量率 $D p$ は(3)式で表 現される。

$$
D p=\Gamma \cdot M \cdot \mathrm{C}_{\lambda} \cdot \mathrm{WAR}(\mathrm{r}) / \mathrm{r}^{2} \longrightarrow(3)
$$

\section{ここで $\mathrm{r}$ は距離である。}

\section{2 線源位置計算法}

\section{2 .1 任意 2 方向撮影法による線源位置の計算}

線源位置計算法には一般的には直角 2 方向撮影法およ びステレオ撮影法がある．直角 2 方向撮影法では Fig. 3 に示すごとく治療歯等の重なりのために同定が困難な場
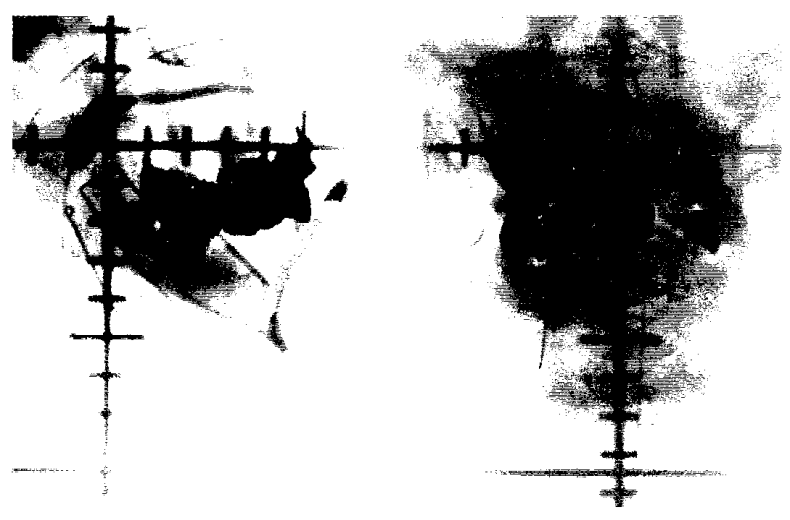

Fig. 3 Anteroposterior and lateral radiographs of a single plane implant in the tongue using $\operatorname{Ir}-192$ pins. Some sources are hidden by the treated teeth.

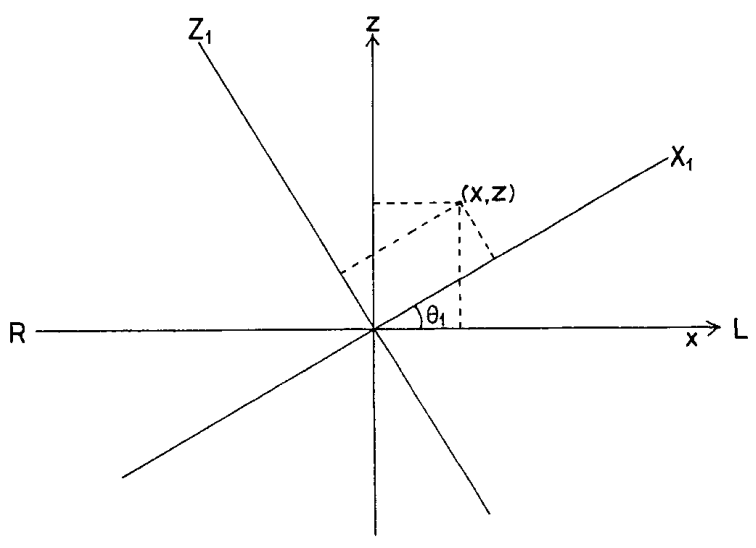

Fig. 4 The principle of three-dimensional reconstruction 1 . The new coordinate system is generated by revolving about the $y$-axis.

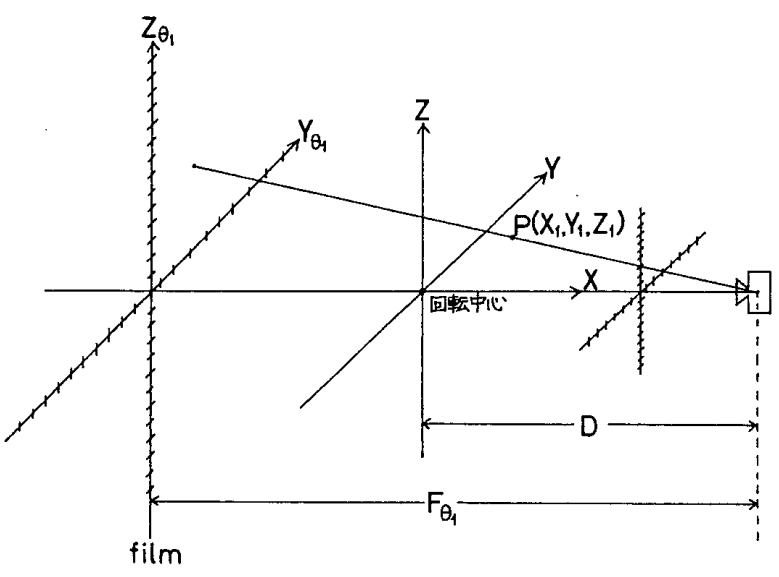

Fig. 5 The principle of three dimensional reconstruction 2. Geometical relationship used in reconstruction of position at point $\mathrm{p}$.

合がある、ステレオ撮影法では $z$ 軸の誤差が大きくなる 欠点がある ${ }^{6), 133,14)}$. ( $x$ 軸：患者の左, $y$ 軸：頭上, $z$ 軸： 前方向）そこでわれわ机は任意 2 方向撮影法による線源 位置計算法を開発した。

Fig. 4 のごとく $y$ 軸を回転軸として $\theta_{1}$ 回転したとき， 新しい座標系を $X_{1}, Y_{1}, Z_{1}$ とすると

$$
\left[\begin{array}{llll}
X_{1} & Y_{1} & Z_{1} & 1
\end{array}\right]=\left[\begin{array}{llll}
x & y & z & 1
\end{array}\right]\left[\begin{array}{cccc}
\cos \theta_{1} & 0 & -\sin \theta_{1} & 0 \\
0 & 1 & 0 & 0 \\
\sin \theta_{1} & 0 & \cos \theta_{1} & 0 \\
0 & 0 & 0 & 1
\end{array}\right]-(4)
$$

同様に $\theta_{2}$ 回転したとき 
$\left[\begin{array}{llll}X_{2} & Y_{2} & Z_{2} & 1\end{array}\right]=\left[\begin{array}{llll}x & y & z & 1\end{array}\right]\left[\begin{array}{cccc}\cos \theta_{2} & 0 & -\sin \theta_{2} & 0 \\ 0 & 1 & 0 & 0 \\ \sin \theta_{2} & 0 & \cos \theta_{2} & 0 \\ 0 & 0 & 0 & 1\end{array}\right]-\{5)$

次に Fig. 5 のように線管球被写体, film が配置さ机 ていると(6)，(7)式が成り立つ。

$$
\left.\begin{array}{l}
Z_{1} /\left(D-X_{1}\right)=Z_{01} / F_{01} \\
Y_{1} /\left(D-X_{1}\right)=Y_{01} / F_{01}
\end{array}\right)-(6)
$$

同様に

$$
\left.\begin{array}{l}
Z_{2} /\left(D-X_{2}\right)=Z_{\theta 2} / F_{02} \\
Y_{2} /\left(D-X_{2}\right)=Y_{\theta 2} / F_{\theta 2}
\end{array}\right)-(7)
$$

(4)，(5)，(6)，(7)式より $X_{1}, Y_{1} ， Z_{1} ， X_{2}, Y_{2}, Z_{2}$ を消 去して $x, y, z$ につて整理すると

$\left[\begin{array}{lll}x & y & z\end{array}\right] \cdot M=\left[\begin{array}{lll}D \cdot Z_{\theta 1} & D \cdot Z_{\theta 2} & D \cdot Y_{\theta 1}\end{array}\right]-(8)$ $M=\left[\begin{array}{cc}-F_{\theta 1} \cdot \sin \theta_{1}+Z_{01} \cdot \cos \theta_{1} & -F_{\theta 2} \cdot \sin \theta_{2}+Z_{\theta 2} \cdot \cos \theta_{2} \\ 0 & 0 \\ F_{\theta 1} \cdot \cos \theta_{1}+Z_{\theta 1} \cdot \sin \theta_{1} & F_{\theta 2} \cdot \cos \theta_{2}+Z_{\theta 2} \cdot \sin \theta_{2}\end{array}\right.$ $Y_{\theta 1} \cdot \cos \theta_{1}$

$$
\left.\begin{array}{c}
F_{\theta 1} \\
Y_{\theta 1} \cdot \sin \theta_{1}
\end{array}\right]
$$

となる.ここで $M$ の逆行列を求め両辺の右側から乗ず れば $x, y, z$ の座標值がもとまる.

任意の 2 方向撮影法より線源位置を求める場合 $\mathrm{X}$ 線束 の交差角が小さいときは誤差が大きくなると考えられる。 そこでその誤差の程度を調べるために三つの点について いくつかの角度で撮影を行い，線源位置を求め比較した。

\section{2 .2 曲がった線源の点線源への置換}

線源が linear な場合は両端を digitizer にて入力し， 3.2 .10 方法で線源位置を求めれば線量計算できる.線源 が曲がっている場合はこの方法は使えない。そこでまず 同一拡大率にて任意 2 方向法で撮影を行う。この場合線 源はシミュレータの回転軸に平行な成分を多く持ってお り，さらに回転軸の近傍にあるものとする。（曲がった線 源が回転軸に垂直な平面内にある時は線源位置を求める ことは不可能である.）次に digitizerにて線源をトレー スし RS-232Cを介してコンピュータに入力する。この 時回転軸に平行な成分を $\mathrm{y}$ 軸とし，まず線源の一端の座 標を計算する。次に $Y_{\theta 1}$ を決め $Y_{\theta 1}=Y_{\theta 2}$ になる $Y_{\theta 2}$ を 捜す。一致したら座標を計算し前の点との距離を求める。 (線源長/分割数) 以上の值になったらその点を分割点と する.この操作を最後の点まで行う. 最後に点線源の位 置と放射能を計算する. 分割線源の長さの合計が 39.1 $\mathrm{mm}$ 以下あるいは $42.1 \mathrm{~mm}$ 以上の時は再度入力する.

なお single-pin 上端の円状の部分は中心に放射能が集

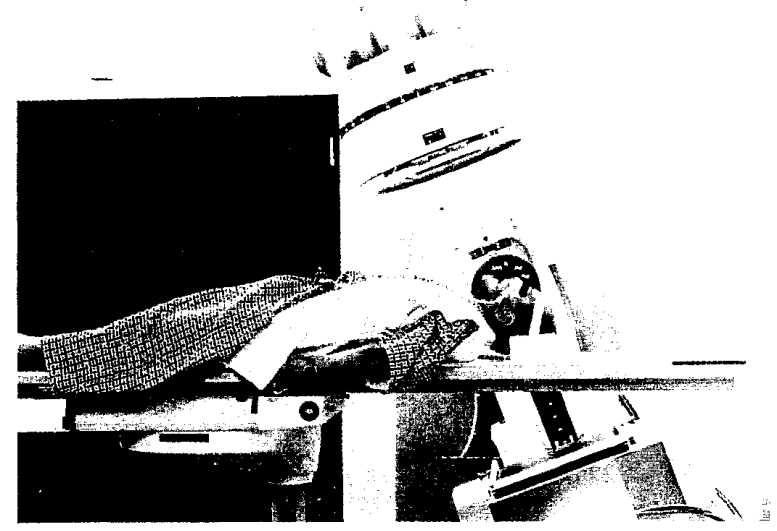

Fig. 6 Positioning to acquire the location of ligual gingiva.

中しているとして1点で計算する.

\section{3 下顎上縁曲線を求める方法}

体軸をシミュレータの回転軸とした任意 2 方向法では, 下顎骨上緑曲縁は回転軸に平行な成分を持たない部分が あるため求めら机ない。

そこでFig.6のごとく寝台を 90 度回転させ，頭側およ び足側よりX線を入射させ撮影を行う。これより 3.2 .20 方法で下顎上縁位置を計算すれば良い。

\section{4 等線量曲線の立体表示}

\section{4 .1 視点座標系への変換}

右手系 3 次元ワールド座標系に抢いて点 $P_{f}$ (look from point） から, 点 $P_{a}$ (look at point) を見るとす る. 点 $P_{f}, P_{a}$ の座標を $\left(x_{f}, y_{f}, z_{f}\right),\left(x_{a}, y_{a}, z_{a}\right)$ とす るとき, 点 $P_{f}$ を原点として直線 $P_{f}-P_{a}$ を $Z$ 軸とする左 手系の座標系を視点座標系と言う。ワールド座標系で記 述された data を視点座標系に変換する行列 $T_{v}$ は(9)で 表現される ${ }^{15)}$.

$T_{v}=T_{1} T_{2} T_{3} T_{4}$

$$
\begin{gathered}
{\left[\begin{array}{cc}
\cos \alpha & \sin \alpha \cdot \sin \beta \\
0 & \cos \beta \\
\sin \alpha & -\cos \alpha \cdot \sin \beta \\
-x_{f} \cos \alpha-z_{f} \cdot \sin \alpha & -x_{f} \cdot \sin \alpha \cdot \sin \beta-y_{f} \cdot \cos \beta \\
\sin \alpha \cdot \cos \beta & 0 \\
-\sin \beta & 0 \\
-\cos \alpha \cdot \cos \beta & 0 \\
-x_{f} \cdot \sin \alpha \cdot \cos \beta+y_{f} \cdot \sin \beta \\
+z_{f} \cdot \cos \alpha \cdot \cos \beta & 1
\end{array}\right] \longrightarrow(9)}
\end{gathered}
$$
ここで

$T_{1}$ : 原点を視点へ平行移動するための変換行列 $T_{2} T_{3}: Z$ 軸を視点の方向に合わせるための変換行列 (方向は逆向き) 
$T_{4}: Z$ 軸の正負を反転させる変換行列

(9)式で $\cos \alpha=\left(z_{f}-z_{a}\right) / \sqrt{\left(x_{f}-x_{a}\right)^{2}+\left(z_{f}-z_{a}\right)^{2}}$

$\sin \alpha=\left(x_{a}-x_{f}\right) / \sqrt{\left(x_{f}-x_{a}\right)^{2}+\left(z_{f}-z_{a}\right)^{2}}$

$\cos \beta=\sqrt{\left(x_{f}-x_{a}\right)^{2}+\left(z_{f}-z_{a}\right)^{2}} /$

$$
\sqrt{\left(x_{f}-x_{a}\right)^{2}+\left(y_{f}-y_{a}\right)^{2}+\left(z_{f}-z_{a}\right)^{2}}
$$

$\sin \beta=\left(y_{f}-y_{a}\right) /$

$$
\sqrt{\left(x_{f}-x_{a}\right)^{2}+\left(y_{f}-y_{a}\right)^{2}+\left(z_{f}-z_{a}\right)^{2}}
$$

である。

\section{4 .2 視点座標系の透視変換}

$\left(x_{e}, y_{e}, z_{e}\right)$ を視点座標系の座標値とするとき透視変換 関係式は(11)となる。

$\left[\begin{array}{llll}x_{e} & y_{e} & z_{e} & 1\end{array}\right] \cdot T_{P}=\left[\begin{array}{llll}X_{P} & Y_{P} & Z_{P} & W_{P}\end{array}\right]-(11)$

ここで $T_{P}$ は

$$
T_{P}=\left[\begin{array}{cccc}
1 & 0 & 0 & 0 \\
0 & 1 & 0 & 0 \\
0 & 0 & k / h & k / h \\
0 & 0 & -k & 0
\end{array}\right]
$$

ここで

$W_{P}$ : 透視変換に必要な值 ( 3 次元射影変換)

$h$ :視点座標系で視点から投影面までの距離

$k:$ screen の $1 / 2$ サイズ（正規化）

実際に投影された $x_{P}, y_{P}$ の座標は

$x_{P}=X_{P} / W_{P} \quad y_{P}=Y_{P} / W_{P}$ となる.

陰線消去は奥の面より等線量曲線を表示し，新しい面 のそれの内部を消去することによって行っている.

Table 1 Check the accuracy of the calculated dose to a division number of source at various perpendicular distance from

\begin{tabular}{|c|c|c|c|c|c|c|c|c|}
\hline 分割数 & $2.5 \mathrm{~mm}$ & 5 & 7.5 & 10 & 15 & 20 & 25 & 30 \\
\hline $\begin{array}{l}\text { シンプソンの } \\
\text { 近似積分 } \\
\text { (20 point) }\end{array}$ & 133.33 & 61.19 & $\mid 37.34$ & 25.62 & 14.35 & 9.13 & $6.28 \mid$ & 4.56 \\
\hline 5 & 182.30 & 64.40 & 37.74 & 25.75 & 14.41 & 9.17 & 6.30 & 4.57 \\
\hline 7 & 154.04 & 61.90 & 37.43 & 25.67 & 14.38 & 9.15 & 6.29 & 4.57 \\
\hline 8 & 120.85 & 60.94 & 37.38 & 25.66 & 14.37 & 9.15 & 6.29 & 4.56 \\
\hline 9 & 142.54 & 61.36 & 37.38 & 25.65 & 14.37 & 9.14 & 6.29 & 4.56 \\
\hline 10 & 127.44 & 61.15 & 37.37 & 25.64 & 14.36 & 9.14 & 6.29 & 4.56 \\
\hline 15 & 134.21 & 61.20 & 37.36 & 25.63 & 14.35 & 9.13 & 6.28 & 4.56 \\
\hline 20 & 133.20 & 61.19 & 37.35 & 25.62 & 14.35 & 9.13 & 6.28 & 4.56 \\
\hline 40 & 133.32 & 61.19 & 37.35 & 25.62 & 14.35 & 9.13 & 6.28 & 4.56 \\
\hline
\end{tabular}
source Isotope: Ir - 192 Activity : 370MBq Active length : $40.4 \mathrm{~mm}$

(rad)

\section{5 等線量曲線で囲まれた面積の計算法}

等線量曲線の point data が左回りに並んでいるもの とすると面積 $S$ は(12)式で表現される.

$$
S=\sum_{i=1}^{n}\left(x_{i}-x_{i+1}\right)\left(\frac{y_{i}+y_{i+1}}{2}\right)-(12)
$$

これに厚さを乗ずれば体積となる。

Table 2 Calculated doses around a linear and curved source.

(1)linear source: with compensation of capsule absorption

(2) linear source : linear source is divided into fifteen point sources

\begin{tabular}{|c|c|c|c|c|c|c|c|c|}
\hline \multicolumn{2}{|c|}{${ }^{x}$} & 2.5 & 5 & 10 & 20 & 30 & 40 & 50 \\
\hline \multirow{4}{*}{0} & (1) & 22 & 78 & .51 & 907 & 0.455 & 0.269 & 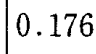 \\
\hline & (2) & & & 2.57 & .915 & & 0.269 & \\
\hline & (3) & .46 & 14.37 & 3.89 & .130 & 525 & 299 & .15 \\
\hline & (1) & 6 & 3.58 & 1.87 & 763 & 402 & 0.244 & 0.16 \\
\hline \multirow{4}{*}{10} & 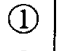 & 97 & 49 & 2.31 & 33 & 127 & 257 & 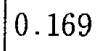 \\
\hline & (2) & .99 & 5.83 & 2.37 & 844 & 430 & 0.258 & c \\
\hline & (3) & 16.35 & 13.26 & 3.40 & 02 & 490 & 0.285 & \\
\hline & (4) & 6.04 & .61 & 1.77 & 10 & 80 & 33 & 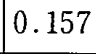 \\
\hline \multirow{4}{*}{0} & & & & & & & & \\
\hline & (2) & 7.34 & 3.44 & 66 & & 30 & 8 & 0.15 \\
\hline & (3) & 2 & | & 66 & & & 0.249 & 0.10 \\
\hline & & 6 & .65 & 30 & 65 & 24 & 08 & 0. \\
\hline \multirow{4}{*}{3} & 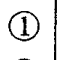 & 534 & 658 & 613 & & 67 & & \\
\hline & (2) & 0.919 & 57 & 90 & 24 & 75 & 88 & 0. \\
\hline & (3) & 0.914 & 75 & 30 & 59 & 97 & 0.202 & 0. \\
\hline & (4) & 369 & 796 & 631 & 387 & 0.252 & 0.174 & 0. \\
\hline & & 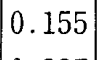 & 36 & 01 & 0.241 & 0.191 & 0.145 & 0.11 \\
\hline & (2) & 0.387 & 0.379 & 0.349 & 0.270 & 0.200 & 0.149 & 0.11 \\
\hline & (3) & 0.385 & 0.380 & 0.357 & 0.282 & 0.211 & 0.158 & 0.11 \\
\hline & (4) & 0.378 & 0.366 & 0.333 & 0.254 & 0.188 & 0.140 & 0.10 \\
\hline \multirow{4}{*}{50} & & & & & & & 0.111 & 0.0 \\
\hline & (2) & 0.220 & 0.218 & 0.209 & 0.179 & 0.146 & 0.116 & 0.09 \\
\hline & & 0.219 & 0.218 & 0.211 & 0.184 & 0.151 & 0.121 & 0.09 \\
\hline & & 0.217 & 0.213 & 0.202 & 0.172 & 0.139 & 0.111 & 0.08 \\
\hline
\end{tabular}

(3)curved source (radius of curvature is $80 \mathrm{~mm}$ ) : outer circle

(4)curved source: inner circle

(rad)

A.L. $\quad 40.4 \mathrm{~mm}$ の Source

P.L. $40.6 \mathrm{~mm}$

$\mathrm{x}$ : 線源中心より線源長軸に直角方向への距離 $[\mathrm{mm}]$ $\mathrm{y}$ : 線源中心より線源長軸方向への距離 $[\mathrm{mm}]$ 


\section{4. 結 果}

\section{1 点線源の分割数と精度}

Table 1 は single-pinの長さで放射能が $10 \mathrm{mCi}(370$ $\mathrm{MBq}$ ）の wireについて線源からの距離と分割数を変え た時の吸収線量である.Simpsonの近似積分值を正しい 値とすると, 線源から $5 \mathrm{~mm}$ の点を土 $1 \%$ 程度にするに は $7 ， 8$ 点に分割す机ば良いことが分かる。すなわち曲 がった線源 $5 \mathrm{~mm}$ 以内を 1 点の点線源に置換すれば良 いであろう。線源から $5 \mathrm{~mm}$ としたのは平面刺入の際, 線源面から $5 \mathrm{~mm}$ 離れた両面を治療面と考えるからで ある。

\section{2 線源の自己吸収と容器吸収および屈曲による 影響}

Table 2 は physical length $40.6 \mathrm{~mm}$, active length 40 . $4 \mathrm{~mm}$ 放射能 $1 \mathrm{mCi}(37 \mathrm{MBq})$ の線源について計算した ものである。

(1)は線源の自己吸収および容器補正を行った計算值で ある。これは $(50,0)$ の位置で容器補正なしの線量にな るように放射能を増加させている。

(2)は線線源を15点の点線源に分割して線量計算した結 果である。容器補正は行っていない.

(3), (4)は直径160 $\mathrm{mm}$ の円弧状に $x y$ 平面上で線源が曲 がったと仮定し両端の位置は $y$ 軸上にあるとして 8 点 に分割して計算したものである。これより吸収補正を行 わないと線源より $5 \mathrm{~mm}$ の位置で $6 \%$ 程度の䛊差を生 じるので自己吸収容器吸収の補正は必要である。また屈 曲した線源を線線源として取り扱うと線源位置が実際の 位置とずれることになるので線量の誤差は大きくなる。 したがって曲率半径 $80 \mathrm{~mm}$ 程度に曲がった線源でも容 器補正を行うより線源位置を正確にする方がより重要で
ある。

\section{3 任意 2 方向撮影法の精度について}

Table 3 は左方向 ( $x$ 軸) からの beam を 0 度, 正面方 向 $(z$ 軸) からを90度としたときに，その間の幾つかの角 度でX線撮影を行い，2枚のレントゲン写真より三つの 点について座標值を求めたものである。角度差 90 度を正 しい值とすると，撮影の角度差が小さいときは撮影方向 の座標值の誤差が大きくなる。

Table 3 より $1 \mathrm{~mm}$ 以内の誤差にするには撮影の角度 差は20度以上必要と考えられる。

\section{4 表 示 例}

Fig. 7 は等線量面, 線源を立体的に表示したものであ る. 線量計算は $3 \mathrm{~mm}$ 間隔で行い70,60, 50, $40 \mathrm{rad} / \mathrm{h} の$ 等線量面を，いくつかの視点で表示している. 体積の計 算もこの等線量曲線を利用する。

Fig. 8 は下顎の線量をグラフ化して CRT に表示した ものである。横軸は歯肉の位置, 縦軸は吸収線量率であ る.

\section{5. 考察・結論}

任意 2 方向法の開発によって Ra 針の場合でも言える ことであるが，線源の見える方向から撮影を行えば良い ので，線源の対応関係が容易に求められるようになった。 ただしこの方法で線源位置を求める場合は二つのX線束 のなす角は20度以上必要である。

つぎに線量計算では，線線源については自己吸収およ び容器吸収の補正は必要であり, 曲がった線源について は線源 $5 \mathrm{~mm}$ 以内を 1 点の点線源に置換すべきである. Ir-192の線源を線線源と点線源に分けることによって， より正確な線量計算が可能になった。

またこのプログラムの開発によって iso-dosecurve が

Table 3 Check the accuracy of the calculated coordinates about three points according to the difference of angle between X-ray beams.

\begin{tabular}{c|c|c|c|c|c|c|c|c|c|c}
\hline 角度差 & 組合せ & $\mathrm{X}_{1}$ & $\mathrm{Y}_{1}$ & $\mathrm{Z}_{1}$ & $\mathrm{X}_{2}$ & $\mathrm{Y}_{2}$ & $\mathrm{Z}_{2}$ & $\mathrm{X}_{3}$ & $\mathrm{Y}_{3}$ & $Z_{3}$ \\
\hline $90^{\circ}$ & $0^{\circ}-90^{\circ}$ & 27.87 & 26.73 & 8.19 & 2.47 & 3.96 & -10.15 & -17.33 & -13.45 & -24.32 \\
$60^{\circ}$ & $30^{\circ}-90^{\circ}$ & 27.98 & 26.63 & 8.19 & 2.39 & 3.82 & -10.10 & -17.23 & -13.70 & -24.19 \\
$45^{\circ}$ & $45^{\circ}-90^{\circ}$ & 28.04 & 26.15 & 8.20 & 2.39 & 3.50 & -10.12 & -17.30 & -13.73 & -23.72 \\
$30^{\circ}$ & $60^{\circ}-90^{\circ}$ & 27.90 & 26.16 & 8.49 & 2.45 & 3.50 & -9.24 & -17.36 & -14.14 & -23.81 \\
$20^{\circ}$ & $70^{\circ}-90^{\circ}$ & 28.01 & 26.09 & 8.92 & 2.52 & 3.44 & -9.14 & -17.30 & -14.12 & -23.87 \\
$15^{\circ}$ & $75^{\circ}-90^{\circ}$ & 27.93 & 26.14 & 9.42 & 2.51 & 3.51 & -7.99 & -17.20 & -14.01 & -22.29 \\
$10^{\circ}$ & $80^{\circ}-90^{\circ}$ & 27.88 & 26.11 & 8.90 & 2.38 & 3.51 & -7.82 & -17.38 & -13.97 & -24.71 \\
$5^{\circ}$ & $85^{\circ}-90^{\circ}$ & 28.02 & 26.11 & 4.96 & 2.44 & 3.38 & -7.69 & -17.26 & -14.16 & -25.34 \\
\hline
\end{tabular}



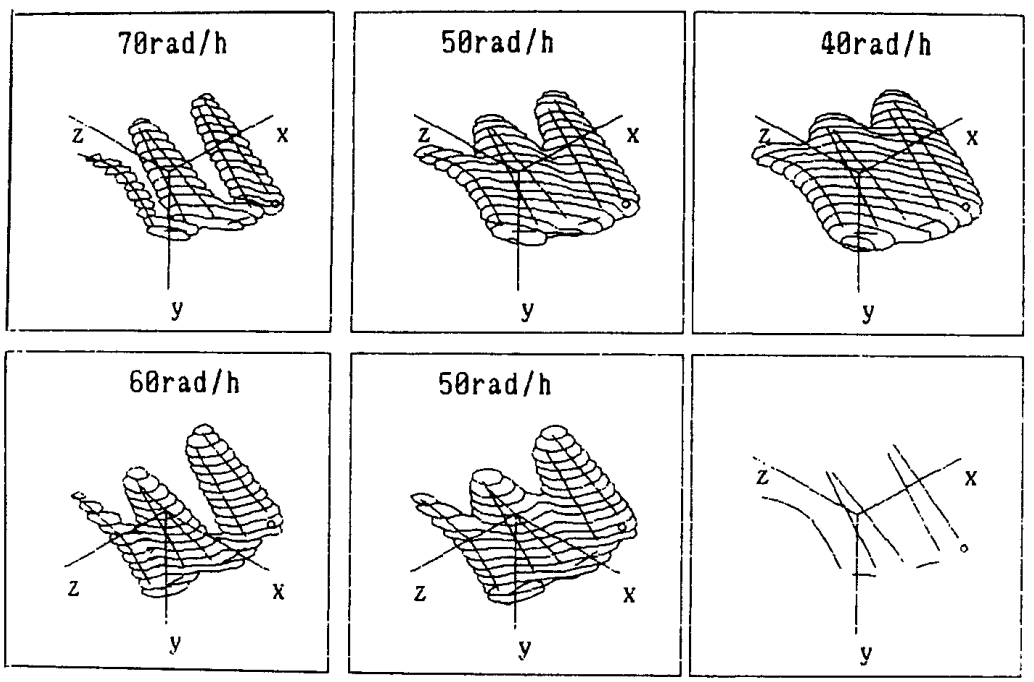

Fig. 7 Display of typical three-dimensional dose distributions from an interstitial implant by a personal computer.

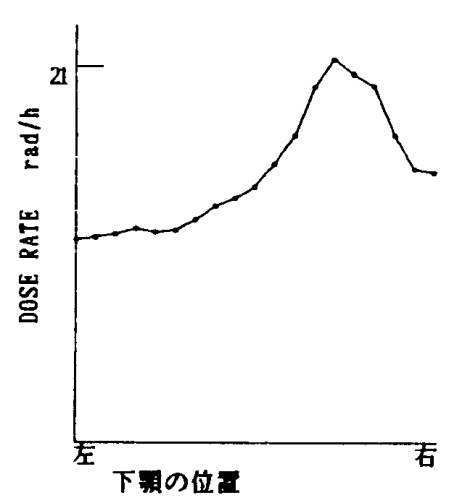

Fig. 8 Absorbed dose rates on line along lingual gingiva.

視点をかえて立体的に観察でき, 線量分布の把挃に役立 つものと思われる。

さらに舌癌の組織内治療で最も問題となる下顎骨の障 害についても，下顎上縁の線量計算を行い，data を蓄積 すれば，予測対応が可能だと考えられる。

ただ立体表示を行うのに 2 時間程の計算が必要なので 多少問題がある.

今後は等線量曲線で围まれた volume および線量率の 影響を考慮したTDF の計算を行い治療成績向上に役立 てたい.

$$
\text { 文献 }
$$

1) 堀内淳一: 舌 口腔. 癌放射線療法（癌の臨床別 冊), 161-169, (1978).

2）水野明夫, 清水正嗣 : 口腔癌の放射線治療後の㴿骨
障害. 歯科時報, 27 (12)，18-21，(1973)。

3）堀内淳一, 奥山武雄, 小西圭介, その他：舌癌の放 射線治療。日医放会誌，37(11)，1041-1051, (1977).

4）奥山武雄, 堀内淳一, 足立 忠：口腔領域に扔ける 放射線骨障害（いわゆる放射線骨壊死）に関する考 察．臨床放射線，14(6)，472-481，(1969)。

5）佐藤 彰，木暮広人，加藤 久：Ir 線源の製造， JAERI-M 9817

6）佐方周防：コンピュー夕による線量計算法密封小線 源治療の線量分布計算. 第41回日本医学放射線学会 物理部会勉強会資料. 51-70，(1981）。

7）内山幸男, 高橋一広, 植田俊男：小型電算機に上る ラジウム線源の線量分布計算. 日放技学誌，32(4), 368-374, (1976).

8）入船寅二：治療計画におけるコンピュータの利用. 癌放射線療法（癌の臨床別冊），72-78，(1978）。

9） modulex (CMS) 線量計算法資料

10）保科正夫, 後藤 功：Ir-192 Hairpinによる組織内 照射の線量分布の解析. 日放技学誌，38(5)，683690, (1982).

11) Cassell, $\mathrm{K}$ : Evaluation of the interstitial and intracavitary programs used on the GE RT/Plan, (1980).

12) Meisberger LL, Keller RJ and Shalek RJ: The effective attenuation in water of the gamma rays of Gold 198, Iridium 192, Cesium 137, Radium 226 and Cobalt 60, Radiology, 90, 953-957, (1968). 
13）高橋賢一：A点線量と線監分布計算法。日放技学誌, 36 (6), 767-777, (1980).

14）速水昭宗，大関修治，森 嘉信：ステレオ撮影法に よる小線源座標の誤差, 日医放会誌, $39(5)$,
(1979).

15）山口富士夫：コンピュータディスプレイによる図形 処理工学, 日刊工業新聞社, 東京, (1981). 